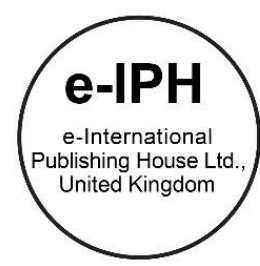

\title{
Landlords' Perception on the Introduction of the Residential Tenancy Act (RTA)
}

\author{
Nurul Ardila Azmi ${ }^{1}$, Mariana Mohamed Osman, Syafiee Shuid
}

${ }^{1}$ Department of Urban and Regional Planning, Kuliyyah of Architecture and Environmental Design, International Islamic University Malaysia, Jalan Gombak, Gombak, 53100 Kuala Lumpur, Malaysia.

ardilaazmi@gmail.com, mariana@iium.edu.my, ssyafiee@iium.edu.my Tel: +60196361812

\begin{abstract}
Deficiency of firm regulations administering the tenancy process has resulted in recurred disputes over a long span of years. This study analyzed the landlord's perception on the introduction of the Residential Tenancy Act (RTA) by examining landlords' acceptance or refusal. This study applied the descriptive analysis method on 50 questionnaire surveys distributed to landlords in Gombak district. Results showed that $70 \%$ of the respondents agreed on the introduction of RTA, while deposit payment is the most preferred principal concept to be consolidated in RTA. These results have recommended strategies to boost the landlord's acceptance of RTA.
\end{abstract}

Keywords: Rental Housing; Landlord; Tenant; Residential Tenancy Act

eISSN: 2398-4287 @ 2019. The Authors. Published for AMER ABRA cE-Bs by e-International Publishing House, Ltd., UK. This is an open access article under the CC BYNC-ND license (http://creativecommons.org/licenses/by-nc-nd/4.0/). Peer-review under responsibility of AMER (Association of Malaysian Environment-Behaviour Researchers), ABRA (Association of Behavioural Researchers on Asians) and cE-Bs (Centre for Environment-Behaviour Studies), Faculty of Architecture, Planning \& Surveying, Universiti Teknologi MARA, Malaysia.

DOI: https://doi.org/10.21834/e-bpj.v4i12.1823

\subsection{Introduction}

Increased house prices beyond affordability and difficulty in renting public housing have indirectly increased the demand for private home rental, especially in major urban areas in Malaysia. Other than that, matching the demand for rental housing among locals and the increasing number of foreign workers/students in the country has also caused private house rentals to increase every year. On the other hand, family processes theoretically mediate the effects of stressors associated with poverty and homelessness on long-term outcomes for parents, children, and families (Linver, Brooks-Gunn \& Kohen, 2002, Weisner, Matheson, Coots \& Bernheimer, 2005). These situations have urged for better management of house rentals to reduce disputes between landlords and tenants. Many other countries have taken steps to alleviate the disputes arising from the lease deal by providing legislation in addressing disputes between the parties involved. Developed countries such as the United Kingdom, Singapore, and Australia have been enacting numerous types of regulations. It is to protect the rights of parties involved in real estate renting transactions, especially for people who cannot afford a home where a tenant's rights need to be protected. However, the rights of homeowners are also crucial to be protected.

Currently, in Malaysia, there is an absence of specific laws governing rental housing; instead, being regarded as a part of the law contract. Though there are several provisions under the National Land Code 1965 (KTN) that clarify aspects of rent and lease as set out in Sections Fifteen (Section 221 to 240), the provisions in the act are still general and brief, not detailing the rights, interests, and obligations of landlords and tenants. It focuses more on aspects of registration and land rent. In addition to the act, there are several other laws (some of which are old and in need of renewal) that also apply to residential rental transactions such as Contract Act 1950, Distress Act 1951, Specific Relief Act 1950 and Civil Laws Act 1956. Researchers), ABRA (Association of Behavioural Researchers on Asians) and cE-Bs (Centre for Environment-Behaviour Studies), Faculty of Architecture, Planning \& Surveying, Universiti Teknologi MARA, Malaysia. 


\subsection{Purpose of the Study}

The purpose of this study was to analyse the landlords' perception on the introduction of the Residential Tenancy Act (RTA) in Malaysia as a tool to administer the tenancy process to protect the landlords' and tenants' rights better. The outcome of this study will reflect the percentages of landlords' agreement on RTA and the reasons behind any support or rejection.

\subsection{Objectives of the Study}

In order to achieve the purpose, three objectives formulated in this study are to analyse landlords' acceptance or refusal towards the introduction of the Residential Tenancy Act, to identify the impacts of new proposed act towards landlords, and to propose appropriate measures and recommendations in response to the findings of the study for better implementation of RTA.

\subsection{Literature Review}

Sharma (2019) defines rental housing as a property occupied by someone other than the owner, for which the owner pays a mutually agreed rent to the owner regularly. The owner of rental housing, which is called the landlord, may be allowed to take certain tax deductions, such as mortgage interest or depreciation. Mae (2008) defines the landlord as the owner of a house, apartment, condominium, or property that is rented or leased to an individual or business. A landlord is usually related closely to the market, which means renting a house to the tenant; it involves the process of business. There are two types of landlords identified in this study, which are private landlord and sub-landlord. A private landlord is a property owner who chooses to rent out their property themselves. They will not use any letting agent or property management company (Wilson \& Flaum, 2003). Instead, they will manage the housing rental directly (Salt \& Miner, 1999). On the other hand, sub-landlord is a person who is being let a residence by a landlord and subsequently sublets it to another tenant (Salt \& Miner, 1999).

Rental housing provides diverse advantages for landlords. Firstly, rental housing yields positive impacts on the overall economy and development of a city as well as the country (Pate, 2015). This finding is supported by (Mariana et al., 2017), where the study indicates that housing poses a significant impact on the competitiveness of the local economy. In a specific country, such as India, rental housing is one of the significant contributors to the economy as it can attract its citizens and immigrants to invest (Kishor, 1986). Secondly, rental housing also gives a broader range of housing prospects. It comes in a variety of configurations which means, the higher one's budget is, the better space will be in terms of location, size, and available amenities (Evan, 2000). Other than that, rental housing also decreases slums and other irregular developments.

From time to time, all landlords operating in the private rental sector faced issues either with their rental homes, tenants, or letting agents. Unfortunately, private landlords from diverse backgrounds are more likely to experience specific housing rental-related issues. According to Shahanaaz Habib (2017), the first issue on rental housing faced by the landlord is high tenant turnover rates. Losing a tenant, a landlord needs to spend time and money to advertise their vacant property, running background checks on new tenants and also arranging the necessary administrative work for changing tenants. Besides, some of the tenants also request to lower the rental amount due to their financial status, and a landlord may agree to follow the tenant's wish. However, it can affect their profitability as a landlord. Another worst case is, some of the tenants run away from their rental property without paying the rent for a few months (Sheila, 2017).

Residential Tenancy Act is an act used to protect landlord and tenant from any problems and disputes related to rental housing (Keith, 2001). The purpose of regulating this act varies according to countries. For example, in South Africa, this act serves as a guideline for a new contract and tort liability in landlord-tenant relations (Weiner, 2014). Azlinor (2012), in her research, found it is very significant to have a specific law to regulate the relationship between landlord and tenant in private residential tenancy. Malaysia is moving towards that direction as the government and related agencies have initiated the plan to introduce RTA. Since RTA is a newly introduced act in Malaysia, there is a need to conduct a study on the perception of the users of RTA in Malaysia, generally and in Gombak district, specifically.

\subsection{Methodology}

\subsection{Study Area}

This study adopted the quantitative method using questionnaire surveys. The questionnaire surveys distributed to 50 landlords living within the periphery of the Gombak district in Selangor. Since the number of foreign workers/students in the country has increased the private house rentals every year, Gombak district is selected as the study area as the district has several numbers of higher institutions.

\subsection{Data Collection}

The survey divides information into three sections, which are Section A (Respondent's Profile), Section B (Landlords' experiences and perceptions towards renting process), and Section C (Landlord's perceptions towards the implementation of RTA) with Likert scale as the scale of measurement. The design of the survey fits the rising issues regarding the tenancy process from various authors. This study distributed the questionnaire survey to 50 samples, and the sampling technique used was purposive sampling, where the study selected only the landlord's living in Gombak district. 


\subsection{Data Analysis}

This study employs two types of analysis methods, which are cross-tabulation and chi-square. Cross-tabulation tables display the relationship between variables, which is then supported by chi-square analysis to prove a significant relationship between the variables. The analysis is beneficial to support researchers' findings and ensure precise results.

\subsection{Findings}

\subsection{Landlords Social Characteristics}

The survey recorded that $84 \%(n=42)$ of respondents are self-managed, and $16 \%(n=8)$ were sub-landlord. Based on the initial cohort of self-manage respondents, $44 \%(n=22)$ were male and $12 \%(n=6)$ were female, while from the sub-landlord respondents, $40 \%(n=20)$ were male and $4 \%(n=2)$ female. Thus, the male respondents contributed $56 \%(n=28)$ of the total responses, and the female respondents contributed $44 \%(n=22)$ of the total responses. In terms of age, $41-50$ years age group recorded as the highest percentage with $42 \%$ $(n=21)$ from self-manage respondents, followed by $51-60$ years age group with $38 \%(n=19)$ and $31-40$ years age group with $4 \%(n=2)$. Similarly, the $41-50$ years age group was recorded as the highest percentage of $10 \%(n=5)$ of sub-landlord respondents, followed by the $31-40$ years age group $6 \%(n=3)$. Based on the findings, the average age of respondents is 55 years old, with the youngest respondent being 35 years old while the oldest is 58 years old. Next, in terms of the marital status of the landlord, married status recorded as the highest percentage for both self-managed landlord and sub-landlord with $80 \%(n=40)$ and $14 \%(n=7)$; while for the single status recorded as the lowest percentage for both landlords' types.

\subsection{Types of Rental Services}

From $100 \%$ of the total respondents, $66 \%$ ( $n=33)$ respondents are running house rental, while $34 \%(n=17)$ respondents are running room rental. In terms of housing types, most of the respondents, both self-manage and sub-landlord respondents are offering high-rise housing such as apartments or condominiums with $42 \%(n=21)$ of self-manage respondents and $12 \%(n=6)$ of sub-landlord respondents. It is followed by terrace house which recorded as the second-highest of the rented house with $32 \%$ ( $n=16$ ) of self-manage respondents and $2 \%(n=1)$ of sub-landlord respondents; while the semi-detached house recorded as the second-lowest among the types of rented house with $12 \%(n=6)$ respondents out of 50 respondents. The findings recorded that there is no bungalow offered as a rented house from both self-manage and sub-landlord respondents.

\subsection{Landlord's Experiences}

The surveys gave four (4) reasons for rental to the respondents, which is inherited property, pension investment, buy-to-let investment, and private or individual property investment. The private or individual property investment consumed the highest percentage of house rental with $62 \%(n=31)$ respondents, followed by buy-to-let investment with $16 \%(n=8)$ respondents, inherited property with $8 \%(n=4)$ and pension investment $4 \%(n=7)$ respondents. In terms of the rental method, there are five methods used by the landlords to advertise their rental houses, such as property website, poster, property agent, newspaper and friend, family, and neighbors. The result illustrated that $66 \%(n=33)$ respondents are using websites such as iBilik, iProperty, or Mudah website to rent their house, followed by friends, family, and neighbors with $34 \%(n=7)$ out of total respondents.

\subsection{Tenancy Deposit}

The surveys also asked about the tenancy deposit on the respondents. This study divided tenancy deposit into three categories which are $1+1$ (collateral + the amount of rent for the first month), $2+1$ (double amount of collateral + the amount of rent for the first month) and $2+1+1$ (collateral + home utility collateral + the amount of rent for the first month). The survey recorded all respondents $100 \%(n=50)$ charged a tenancy deposit to their tenants. The majority of the respondents choose to conduct $1+1$ types of deposit, with $84 \%$ ( $n=42)$ out of the total respondents. In the ascendant with that, the highest amount of deposit imposed by $1+1$ deposit was between RM500 to RM799 with $52 \%$ ( $n=26$ ) respondents, followed by RM200 to RM499 with 20\% ( $n=10)$ respondents, RM800 to RM1099 with 10\% ( $n=5)$ respondents, and lastly, RM1100 to RM1399 with only $2 \%(n=1)$ respondent. For $2+1$ types of tenancy deposit, RM500 to RM799 was recorded as the highest range of amount imposed by the respondents with $8 \%(n=4)$ respondents, followed by RM800 to RM1099 with $6 \%(n=3)$ respondents and RM1100 to RM1399 with 2\% $(n=1)$ respondent. No respondents were imposing the tenancy deposit using $2+1+1$ types.

\subsection{Landlords' Perception of the Introduction of the Residential Tenancy Act}

In terms of awareness on the introduction of RTA, the surveys recorded that $66 \%$ (33) respondents acknowledged the introduction of RTA. Landlords have been renting their house for many years, thus, familiarize themselves with the changes happening towards their surroundings.

The respondents then were asked on their agreement with the introduction of RTA. The result revealed that $70 \%(n=35)$ of respondents agreed with the introduction of RTA and supported the idea of the government to imposed this act in the housing rental sector. The respondents were then required to present and rank their personal opinion on the agreement. This study uses rating score analysis to measure their perception to identify variables with higher and lower weighted score. Each choice was assigned a numerical value where $3=$ strongly agree, $2=$ agree, $1=$ disagree, and $0=$ strongly disagree with each other. 
The survey result indicated that the deposit term payment (including the types of deposit to be paid by the tenant and the landlord's return of the deposit to the tenant) was the main term agreed upon by the respondents to incorporate into RTA. The weighted score is 126 , with $58 \%(n=29)$ respondents strongly agreed. The following highest weighted score of 123 is the term on the amount of rent to be paid by tenant (including increase of the rental amount for the next few years) and moving out at the end of the rental term where the result explicated $56 \%(n=28)$ and $54 \%(n=27)$ of respondents strongly agreed. The less significant reason is the perception of the details of the council tax, utilities, and other charges for services included in the rent. The weighted score is 56 where $58 \%$ ( $n=29)$ responded disagree, $10 \%(n=5)$ responded strongly agree, $12 \%(n=6)$ responded agree and the remaining $16 \%(n=8)$ responded strongly disagree.

Other than that, $30 \%(n=15)$ of respondents reject the introduction of the RTA though they are aware of the benefits. The main refusal factors were lack of knowledge about the Residential Tenancy Act, with $72 \%(n=36)$ of respondents, followed by higher cost of implementation and less awareness from the landlord regarding the implementation of RTA, with $12 \%(n=6)$ and $12 \%(n=6)$ respondents, respectively. Hence, this study provides a relationship hypothesis on landlords' refusal towards the introduction of RTA and the refusal factors for further clarifications.

\subsection{Significant Relationship Between Landlords' Refusal towards the Introduction of the Residential Tenancy Act and the Refusal Factors}

Based on Table 1, the finding indicated that $88 \%(n=44)$ of the respondents did not require the Residential Tenancy Act. This result showed a contradictory analysis with the agreement on the introduction of RTA. The highest refusal factor is a lack of knowledge regarding RTA with $72 \%(n=36)$ from the total respondents. In this regard, this study carried out the Chi-Square test to verify the significance of the relationship between these two elements.

Table 1 Cross Tabulation Table of Landlords' Requiring the Residential Tenancy Act and the Refusal Factors

\begin{tabular}{|c|c|c|c|c|c|c|c|c|c|}
\hline \multirow{3}{*}{ Variable } & \multirow{3}{*}{ Component } & \multicolumn{6}{|c|}{ Refusal Factors } & \multirow{2}{*}{\multicolumn{2}{|c|}{ Total }} \\
\hline & & \multicolumn{2}{|c|}{$\begin{array}{l}\text { Higher Cost of } \\
\text { Implementation }\end{array}$} & \multicolumn{2}{|c|}{$\begin{array}{l}\text { Lack of Knowledge } \\
\text { regarding the Residential } \\
\text { Tenancy Act }\end{array}$} & \multicolumn{2}{|c|}{$\begin{array}{l}\text { Lack of Awareness on the } \\
\text { implementation of RTA }\end{array}$} & & \\
\hline & & Unit & $\%$ & Unit & $\%$ & Unit & $\%$ & Unit & $\%$ \\
\hline \multirow{2}{*}{$\begin{array}{l}\text { Require the Residential } \\
\text { Tenancy Act }\end{array}$} & Yes & 6 & 12.0 & 0 & 00.0 & 0 & 0.0 & 6 & 12.0 \\
\hline & No & 2 & 4.0 & 36 & 72.0 & 6 & 12.0 & 44 & 88.0 \\
\hline
\end{tabular}

(Source: Questionnaire Survey, 2019)

Table 2 Relationship Between Landlords' Requiring the Residential Tenancy Act and the Refusal Factors

\begin{tabular}{|l|c|c|c|}
\hline & Value & df & $\begin{array}{c}\text { Asymptotic Significance } \\
\text { (2-sided) }\end{array}$ \\
\hline Pearson Chi-Square & $19.431^{\mathrm{a}}$ & 2 & .000 \\
\hline Likelihood Ratio & 13.384 & 2 & .001 \\
\hline Linear-by-Linear Association & 12.374 & 1 & .000 \\
\hline N of Valid Cases & 50 & & \\
\hline
\end{tabular}

(Source: Questionnaire Survey, 2019)

Based on Table 2 above, the result showed that the degree of freedom is 2 with 19.431 calculated chi-square. Meanwhile, the result of Asymptotic Significance is less than 0.05 , which is 0.000 . Therefore, both of the variables are significantly related. In conclusion, the result infers that respondents did not require the implementation of RTA on them due to a lack of knowledge regarding RTA.

\subsection{Discussion}

\subsection{Experience in Managing Rental Housing}

$84 \%(n=42)$ of the respondents managed the rented house on their own, and $56 \%(n=28)$ of the respondents are male. The finding showed that male gender controlled most of the rental homes. The majority of the respondents were renting their houses for more than five years. This result corresponds with the amount of rent charged by the landlord, whereby there is a significant relationship between the variables. All respondents, $100 \%(n=50)$, agreed that they have the same experience in dealing with a problematic tenant. The major problem they need to contend with is that some of the tenants did not properly clean the house and were irresponsible for the cleanliness of the house. This result is related to the satisfaction of the respondents towards the tenant, which happened to gain only $46 \%$ ( $n=23)$ out of the total respondents.

\subsection{Landlords' Perception of the Introduction of the Residential Tenancy Act}

The finding indicates that $66 \%(n=33)$ of the respondents aware of the introduction of the RTA. Following this, 58\% ( $n=29)$ of respondents chose to include the term on the payment of deposit by a tenant in the act. This term also includes the forms of deposit to be paid by the tenant and the landlord's return to the tenant. The purpose is to ensure that the tenant pays the deposit charged to them, and the tenant will get the deposit in return when it is necessary.

$70 \%(n=35)$ of the respondents agreed with the introduction of the RTA as they are aware of the benefits of it, precisely for landlords' matters. However, $30 \%(n=15)$ of the respondents refuse to impose the act in the housing rental process. Some of the respondents highlight that they lacked knowledge regarding the implementation of the RTA. They do not have full exposure to the implementation of 
the RTA though they have involved in the housing rental sector for ages. This result proved that there is a significant relationship between the landlords' refusal and the refusal factors.

Respondents believed, the more extended period they have contributed to the housing rental sector, the lesser they require the act. They prefer to solve the issues regarding the housing rental process outside the control of the act. The finding also indicates that an increase in age reduces the need for the act towards an individual. Since most of the respondents aged 40 years and above, they thought that they would not require the act as it may involve a long and challenging process.

Although most landlords are aware of the introduction of the RTA, they were not well exposed to the details process related to the act and the benefits gained from its implementation. Awareness towards the RTA needs to improve. Therefore, the responsible authorities need to formulate better initiatives to increase landlords' awareness apart from improving the approaches used in the introduction of the RTA.

\subsection{Limitations of Study}

This study was built for landlords' within the area of Gombak district, and the other district was not selected. Other than that, this study limits the focus on landlords. The tenants' perception on the implementation of RTA is not explored.

\subsection{Conclusion and Recommendations}

This study infers that $70 \%(n=35)$ of the respondents agreed with the introduction of the RTA as they are aware of the benefits of it, precisely for landlords' matters. They supported the idea of the government to imposed this act in the housing rental sector.

This study provides some recommendations and suggestions in response to the results and evaluation in order to improve RTA implementation. Mariana, Muhammad Adib, Syakir Amir, \& Mansor (2018) suggest that responsible authorities need to execute more proactive approaches and housing strategies for a better living environment. In regards to that, this study has set up two recommendations, whereby the first recommendations cover the matters concerning the introduction of the act. In contrast, the second concerns are the approach to overcome the refusal of landlords towards the implementation of the act. The first recommendation is to update the terminology used in the RTA. The findings have presented three chosen terms by the landlords, which are payment of deposit by the tenant, amount of rent, and the termination of rental. Thus, the existing terminologies proposed for the act should be revised ideally in order to achieve the maximum target of achievement on the implementation of the RTA. The next recommendation is to set up a minimum standard on rental properties. It includes setting up a clear objective on the introduction of the RTA, creating a systematic database to collect the landlords' and tenants' data, and providing a standard regulation for landlords to manage their rental properties precisely on the matters of the rental rate to avoid rent arrears. These recommendations may help urban planners to govern the rental housing sector alongside with participatory planning with the community and optimize the participation of landlords' in the planning of the RTA. This study is essential to improve the sustainability of the housing sector in Malaysia.

Further research about the perception of landlords at other districts and states would be beneficial for the betterment of RTA's implementation. Besides, a study on tenants' perception is also seen as crucial to provide fair treatment for both tenants and landlords.

\section{Acknowledgments}

We would like to thank the landlords' in Gombak district who had responded to the questionnaire survey and participated in this study.

\section{References}

Azlinor, S. (2012). A Conceptual Study on Landlord and Tenant Law in Peninsular Malaysia: A Focus on Private Residential Tenancy, 7(1).

Linver, M.R., Brooks-Gunn, J., Kohen, D.E. (2002). Family Processes as Pathways from Income to Young Children's Development. Developmental Psychology, 38, 719734.

Mae, F. (2008). Becoming A Landlord: Rewards, Risks, and Responsibilities., (October).

Mariana, M. O., Muhammad Adib, R., Nasriah, S., Noor Suzilawati, R., Muhammad Faris, A., \& Najihan, K. (2017). Housing Affordability in the State of Johor, 15(April 2016), 347-356.

Mariana, M. O., Muhammad Adib, R., Syakir Amir, A. R., \& Mansor, I. (2018). The Basic Criteria for the Provision of Affordable Housing in Melaka, $16(2)$, 73-82.

National Land Code 1965 (Act 56).

Saltz, S. G., \& Miner, M. P. (1999). Subleases: A New Approach - A Proposal. Real Property, Probate, and Trust Journal, 34.

Shahanaaz Habib. (2017, August 6) Unclassified: Landlords vs. Tenants - Nation | The Star Online.

Sharma, A. (2019). What is rental housing? [online] https://www.livemint.com.

Singh, B. (2015, September 10) Dealing with difficult tenants - Law for Everyone | The Star Online. 
Weiner, D. J. (2014). Author/speaker, Caught in The Middle: Practical Drafting Tips for Sub-landlords, South Texas College of Law, 28th Annual Real Estate Law Conference. Liskow \& Lewis E-Newsletter Series.

Weisner, T. S., Matheson, C.S, Coots, J., Bernheimer, L. P. (2005). Sustainability of Daily Routines as A Family Outcome. In A. Maynard \& M. Martini (Eds.), Learning in Cultural Context: Family, Peers, and School (pp. 41-73). New York, NY: Kluwer Academic/ Plenum Press Publishers.

Wilson, R. C. W., \& Flaum, P. C. (n.d.). Assignment and subletting: Balancing Landlord and Tenant Interest. p. 9-11 